\title{
Grafik Tasarımı Bölümü Öğrenme Çıktılarının 21. Yüzyıl Becerileri Temelinde İncelenmesi
}

\section{An Analysis on Learning Outcomes of Graphic Design Department through The 21st Century Skills}

\section{Aytaç Özmutlu}

Dr. Öğr. Üyesi, Ordu Üniversitesi, Güzel Sanatlar Fakültesi, Grafik Tasarım Bölümü

email: aytacozmutlu@odu.edu.tr (DORCID ID: https://orcid.org/0000-0003-2649-083X

\section{Emel Bayrak Özmutlu}

Dr. Öğr. Üyesi, Ordu Üniversitesi, Eğitim Fakültesi, Temel Eğitim Bölümü

email: emelozmutlu@odu.edu.tr (DORCID ID: https://orcid.org/0000-0002-1222-3557.

\begin{abstract}
$\underline{V}_{\text {for Authors }}^{\text {iThesearchers }}$ 'Bu makale bilimsel etik ve kurallara uygun hazırlanmış ve intihal incelemesinden geçirilmiștir. Etik kurul onayı gerektirmemektedir.

Atıf (APA 6)/To cite this article

Özmutlu, A., \& Bayrak Özmutlu, E. (2021). Grafik tasarımı bölümü öğrenme çıktılarının 21. yüzyıl becerileri temelinde incelenmesi. Atatürk Üniversitesi Güzel Sanatlar Enstitüsü Dergisi, 27(46), 138-152. https://doi.org/10.35247/ataunigsed.844115
\end{abstract}

Makale Gönderim Tarihi/Received: 20/12/2020

Makale Kabul Tarihi/Accepted: 10/02/2021

Makale Yayın Tarihi/Published: 29/03/2021

Research Article/Araștırma Makalesi

$\ddot{\mathbf{O} z}$

Bu araștırmada, Türkiye'de grafik tasarımı bölümlerinde yürürlükte olan öğretim programları öğrenme çıktılarının 21. yüzyıl becerileri temelinde incelenmesi amaçlanmaktadır. Araștırmada 2020 yılı itibariyle Yükseköğretim Kurulu web sayasında yer alan üniversiteler arasından, aktif durumda olup resmi internet sayfalarından öğretim programı çıtılarına ulaşılan 20 üniversitenin toplam 292 öğrenme çıktısı incelenmiştir. Araștırmanın veri analizi sürecinde tekrara dayalı okuma, açık kodlama ve sürekli karşılaștırma adımlarının uygulandığı ayrıntılı bir analiz süreci takip edilmiştir. Araştırma bulguları incelenen 292 öğrenme çıtısının 339 beceri kodu temelinde kodlandığını göstermektedir. Öğrenme çıktılarının en fazla \%51.7 ile öğrenme ve inovasyon becerilerini geliştirmeyi amaçladığı görülmektedir. Araștırma kapsamında incelenen grafik tasarım öğretim programları öğrenme çıktılarının ikinci olarak en fazla geliștirmeyi amaçladığı beceri alanının \%21.6'llk bir oranla yaşam ve kariyer becerileri olduğu görülmektedir. Araştırma kapsamında üçüncü sırada \%15.1'lik bir oranla bilgi ve medya teknolojileri becerilerinin yer aldığı görülmektedir. Arastırmada grafik tasarım öğretim programlarında genel kültür bilgisi ve mesleki bilgiye odaklı olduğu belirlenen öğrenme çıtıları diğer öğrenme çıktıları başlığı altında incelenmiştir. Bu başlık altında yer alan öğrenme çıktılarının büyük bir bölümünün meslek bilgisi (\%10.3) ile ilgili olduğu görülürken genel kültür becerilerinin $\% 1.2$ oranında yere sahip olduğu görülmektedir.

Anahtar kelimeler: Grafik Tasarım, Grafik Tasarım Eğitimi, Öğretim Programları, 21.Yüzyıl Becerileri

\begin{abstract}
This research aims to analyze the curriculum learning outcomes of the graphic design departments in Turkey through 21 st-century skills. In the research, a total of 292 learning outcomes of 20 universities, which are active among the universities on the website of the Council of Higher Education as of 2020, and whose academic learning outcomes have been accessed from the official websites, were examined. During the data analysis process of the research, a detailed analysis process in which repetitive reading, open coding, and continuous comparison steps were followed. The research findings show that the 292 learning outcomes examined were encoded basing on 339 skill codes. It is seen that the learning outcomes aim to improve learning and innovation skills at most with $51.7 \%$. It is seen that the second most developed skill area of graphic design learning outcomes examined within the scope of the research is life and career skills with a rate of $21.6 \%$. Within the scope of the research, it is seen that information and media technologies skills take the third place with a rate of $15.1 \%$. In the research, the learning outcomes determined to be focused on general cultural knowledge and professional knowledge in graphic design curricula were examined under the heading of other learning outcomes. While most of the learning outcomes under this heading are related to professional knowledge $(10.3 \%)$, general culture skills are at a very low rate $(1.2 \%)$
\end{abstract}

Keywords: Graphic Design, Graphic Design Education, Curriculum, 21st Century Skills

\section{Giriş}

21. yüzyıl bilim ve teknolojinin hızla ilerlediği bunun yanı sıra kültür ve eğitim alanında da pek çok yenilik ve gelişimin ortaya çıktığı bir dönemin başlangıç noktası haline gelmiştir (Alkış, 2020). 21.yüzyılda şahit olunan toplumsal, ekonomik, siyasi ve teknolojik gelişmeler ihtiyaç duyulan nitelikli birey özelliklerinin de değişmesine neden olmuştur (Cansoy, 2018). Dünyanın pek çok ülkesinde bu gereklilikler temelinde program geliştirme çalışmaları devam etmekte ve bu konu, çok sayıda politik metinde kendine yer bulmaktadır. Geleceğin eğitimi konusunda akademik yazın ve politik metinler, öğrencilerin zihinsel becerilerinin geliştirilmesi gerekliliği üzerinde uzlaşmış durumdadır (Bayrak Özmutlu, 2020). 21. yüzyıl bireylerinin hem eğitim, hem de iş hayatında başarıyı elde edebilmeleri ve artan talepleri karşılayabilmeleri için çeşitli becerilere hâkim olmaları gerekmektedir. Üretken ve yaratıcı olma, sorunları çözebilme, kendi kendini yönlendirebilme, iletişim becerisi ve sosyal beceriler 21. yüzyıl bireylerinde sahip olunması beklenen beceriler arasında sayılabilir (Uluyol ve Eryılmaz, 2015). 
İçinde bulunduğumuz yüzyılda söz konusu dönüşüm iş dünyasında da kendini göstermektedir. İş hayatını çevreleyen bilgi ve teknolojik şartlar bireylerin zengin donanımlara sahip olmasını gerektirmektedir. İş hayatı bireylerden temel düzey düşünme becerilerinin üzerinde bir performans beklemektedir. Temel düzey düşünme becerilerinin kullanıldığı meslekler üst düzey düşünme ve uzmanlaşma gerektiren mesleklere yerini bırakmaktadır (Trilling ve Fadel, 2009). İfade edilen gerçeklik yükseköğretim programları üzerinde belirleyici unsurlardan biri olarak değerlendirilebilir.

Beceriler, geleceğin dünyasının bireylerinden beklenen gerekliliklerin yerine getirilebilmesi konusunda önemli bir öğrenme çıktısı haline gelmiştir. 21.yüzyıl becerileri bu yüzyılın bilgi toplumu koşul ve beklentileri içinde bireylerin iyi vatandaşlar ve nitelikli iş görenler olmalarını sağlayan becerilerdir (Ananiadou ve Claro, 2009). Bu beceriler sadece okul yaşamı ile sınırlı olmayıp iş yaşamı ve sosyal yaşamda da ihtiyaç duyulan bilişsel, davranışsal veya duyuşsal alanları içine almaktadır. 21. yüzyıl becerileri genel anlamda öğrenme ve yenilenme becerileri, yaşam ve kariyer becerileri, bilgi, medya ve teknoloji becerileri olmak üzere üç temel alanda sınıflandırılmaktadır (Anagün ve diğerleri, 2016). 21. yüzyıl Öğrenim için Ortaklık, 2015 (Partnership for 21st Century Learning) tarafından "öğrenme ve yenilik becerileri”, “dijital okuryazarlık becerileri” ve "kariyer ve yaşam becerileri” olarak sınıflanmış ve her beceri alt başlıklarla incelemiş ve açıklanmıştır. Çağımızda tüm bireylerin hangi alandan olursa olsun bu becerilere sahip olmaları büyük bir gerekliliği oluşturmaktadır.

21. yüzyıl becerileri pek çok farklı kurum ve kuruluş tarafından farklı isimler altında sınıflandırılmıştır. Yalçın (2018)' in ifade ettiğine göre bu becerilere "gerekli beceriler (necessary skills)", "istihdam edilebilirlik becerileri (employability skills)", "temel yeterlikler (key competences)", "hayatta kalma becerileri (survival skills)", "derin öğrenme becerileri (deep learning skills)" gibi isimler vermişlerdir. 21. yüzyıl becerileri ile ilgili olarak çeşitli kurum ve kuruluşlara ait sinıflamalar olduğu (NCREL [North Central Regional Educational Laboratory], P21 [Partnership for 21st Century Learning], ATCS [Assessment and Teaching of 21st Century Skills], ASIA Society [Asia Society Partnership for Global Learning], OECD [Organization for Economic Cooperation and Development], EU [European Union], ISTE [International Society for Technology in Education]) görülmektedir (Anagün ve diğerleri, 2016). Sınıflamalar incelendiğinde yaratıcılık, eleştirel düşünme, problem çözme, nitelikli ürün oluşturma becerilerinin en fazla yer verilen beceriler arasındadır (Voogt ve Roblin, 2012).

Türkiye'de bu kapsamda yürütülen çalışmalara bakıldığında Milli Eğitim Bakanlı̆̆ı'nda 2005 yılında uygulamaya konulan öğretim programları ile 21. yüzyıl becerileri Türk eğitim sisteminde yer bulmaya başlamıştır (Millî Eğitim Bakanlığı, 2005). Avrupa Yeterlilikler Çerçevesi ile uyumlu olacak şekilde ilk, orta ve yükseköğretim dâhil, meslekî, genel ve akademik eğitim ve öğretim programları ve diğer öğrenme yollarıyla kazanılan tüm yeterlilik esaslarını gösteren tasarlanan Türkiye Yeterlilikler Çerçevesi (TYÇ) de Türkiye'de 21. yüzyıl becerileri kapsamında atılan adımlar arasında gösterilebilir. Bakanlar Kurulunun 2015/8213 sayılı Kararıyla 19 Kasım 2015 tarihli ve 29537 sayılı Resmî Gazete'de yayımlanarak yürürlüğe giren Türkiye Yeterlilikler Çerçevesinin Uygulanmasına İlişkin Usul ve Esaslar Hakkında Yönetmelik” ile; ülkemizdeki mevcut yeterliliklerin kapsamlı bir şekilde bir araya getirilmesi, yeterliliklerin kalitesinin artırılması, hayat boyu öğrenmenin yaygınlaştırılması ve sistemli bir şekilde desteklenmesi, ulusal ve uluslararası şeffaflığın ve tanınırlığının en üst düzeyde karşılanması ve toplumun tüm bireyleri için eğitim ve istihdam fırsatları yaratılması hedeflenmektedir.

Eğitimde 21. yüzyıl becerilerinin tüm bireylere kazandırılması gerekliliği fikri gün geçtikçe artarak yaygınlaşmaktadır. Bu durum her düzeyde öğretim programları içerisinde 21. yüzyıl becerilerinin daha detaylı ve sistematik boyutta yer alması zorunluluğu doğmaktadır (Ekici ve diğerleri, 2017). 21. yüzyıl becerilerinin öneminin artması sonucu, bu becerilerin temelden en baştan tanımlanması, kapsamının ayrıntılı olarak incelenmesi, bu becerilerin neler olduğu ve kabul gören ortak bir sınıflanmanın yapılması önem arz etmektedir (Yalçın, 2018). 21. yüzyıl becerileri olarak ifade edilen becerilerin bireylere kazandırılması amacıyla eğitim programlarına entegre edilmesi önem taşımaktadır. Bireylere istenilen bu nitelikleri kazandırarak onları hayata hazırlama konusunda, bireyin yetiştirilmesinde ve 21. yüzyılın öğrenci özellikleri farkındalıklarının oluşturulmasında yükseköğretim kurumları ciddi bir sorumluluğa sahiptir (Günüç ve diğerleri, 2013). Bu durum yükseköğretim programlarının 21.yüzyıl becerileri ile uyumlu bir anlayışa sahip olması gerektiğini düşündürmektedir.

Yaşadığımız dönüşümünün temel dinamiklerinden olan iletişim ve teknolojideki değişim ve yeniliklerden doğrudan etkilenen eğitim alanlarından biri de grafik tasarımdır. Akademik bir disiplin olarak grafik tasarım eğitimi, her türlü görsel tasarım problemini çözebilen, çağın gerekliliklerine uygun donanımlarını yetkin olarak kullanan, yaratıcı düşünme becerilerine sahip tasarımcılar yetiştirmeyi amaçlamaktadır (Anadolu Üniversitesi, t.y.). 21. yüzyılda her alanda yaşanan değişim ve gelişmeler grafik tasarımcılarından beklenen nitelikleri doğrudan etkilemiştir. Grafik Tasarım alanı toplumsal dönüşümleri en yakından izlemesi ve öngörmesi gereken alanlardan birini oluşturmaktadır. Bunun yanında, tasarımların gerçekleştirildiği ve paylaşıldığı ortamların elektronik tabanlı olması grafik tasarımcıların iletişim teknolojileri alanındaki değişimlere ayak uydurabilmesinin ne denli önemli olduğunu da göstermektedir. Elektronik ortamlarda ve yazılım mühendisliği alanında görülen hızlı dönüşüm artık grafik tasarımda ortaya konulan ürünün formunu ve tasarım sürecini belirleyen başlıca etken olmuştur. Ürünün 
sergilendiği veya müşteriyle buluştuğu sayısal ortamların özellikleri veya teknik olasılıkları grafik tasarım sürecinin planlamasına mutlaka dâhil edilmektedir. Dolayısıyla özellikle grafik tasarım eğitiminde öğretim programlarının yapılandırılması aşamasında bu gerçek göz ardı edilmemelidir. Teknolojik yeniliklerin iletişim tasarımı dâhil olmak üzere birçok alana yaygın olarak nüfuz ettiğini ve tasarımcıların sahip olması gereken yetenekleri derinden etkilediğini öne süren Colucci (2011)'e tasarım eğitiminin misyonu, öğrencilerin akademik programlar dâhilinde ve sonrasında potansiyellerini geliştirmelerine ve iş dünyasında ve toplumsal alandaki dönüşümlerle yüzleşebilmelerine yardımcı olmaksa, teknolojik boyut tasarım eğitimi programlarında dikkate alınması gereken hayati bir etkendir. Diğer yandan bir grafik tasarımcının tasarım sürecinde üst düzey düşünme becerilerini aktif bir biçimde kullanması gerekmektedir. Tasarım bir açıdan eleştirel ve yaratıcı bir problem çözme süreci olarak tanımlanabilir. Bir tasarımcının her tasarımında bilgi ve becerilerini yepyeni bağlamlara transfer etmesi gerekmektedir. Ayrıca grafik tasarımcıların çalışma ortamları dikkate alındığında iletişim ve işbirliği; liderlik ve sorumluluk; girişim ve kendini yönlendirme; esneklik ve uyum becerileri de önemli beceriler olarak karşımıza çıkmaktadır.

Grafik tasarım bölümleri görsel iletişim sektöründe çalışacak tasarımcılar yetiştirmektedir. Dolayısıyla grafik tasarım bölümünden mezun olan öğrenciler 21.yüzyıl koşullarından en fazla etkilenecek alanlardan birinde çalışıyor olacaklardır. Bu nedenle grafik tasarım öğrencilerinin henüz eğitim aşamasındayken ilgili sektörle tanışması, yenilikleri yakından takip etmesi ve uygulayarak öğrenmesi gerekmektedir. 21. yüzyıl becerilerinin grafik tasarımı alan yeterlilikleriyle ne denli yakın bağlantılara sahip olduğu göz önünde bulundurulduğunda üniversitelerin iş dünyası ile daha işlevsel ve derin ilişkiler kurmasının önemi anlaşılacaktır. Heller ve Talarico (2011)'e göre tasarım, her zaman iş dünyasının bileşenlerinden biri olarak görülmüş olsa da 21. yüzyılda iş dünyasına her zamankinden daha fazla entegre edilmelidir. Söz konusu birliktelikte tasarımcılar, fikir üretenler olarak bu sürece öncülük etmelidir.

Öğretim programlarının 21. yüzyıl becerilerini geliştirme konusunda sahip olduğu kapasiteyi inceleme konusunda en önemli bileşeni öğrenme çıktılarıdır. Programlarda öğrenme çıktısı olarak yer almayan bir beceri, yükseköğretim kurumlarında yürütülmekte olan öğretim uygulamalarında da kendine yer bulamayacaktır. Bu açıdan öğretim programlarındaki öğrenme çıktılarının 21. yüzyıl becerileri açısından incelenmesi, programların 21. yüzyıl becerilerinin gelişimini destekleme konusundaki durumuna ilişkin değerlendirmede bulunabilmeyi mümkün kılmaktadır. Bu sayede öğretim programlarında hangi 21.yüzyıl becerilerine yer verildiği ve bu becerilerin programlarda hangi ağırlıkta yer aldığını inceleyebilmek mümkün olmaktadır. Bu araştırma uygulanmakta olan grafik tasarımı öğretim programlarının 21. yüzyıl becerilerini geliştirme konusunda sahip olduğu potansiyeli inceleyebilmeyi mümkün kılmaktadır. Araştırma bulgularının, grafik tasarımı öğretim programlarının 21.yüzyıl becerilerini geliştirme konusundaki potansiyelinden en üst düzeyde yararlanma konusunda program geliştirme sürecine rehberlik edici bilgiler sağladığı düşünülmektedir.

Alanyazında, 21.yüzyıl becerilerinin ölçülmesinin (Yalçın, 2018; Anagün ve diğerleri., 2016); bu konuda yapılmış olan sınıflandırmaların (Cansoy, 2018), öğretmenlerin alg1 ve yeterliliklerinin incelendiği (Gürültü ve diğerleri, 2019; Cemaloğlu ve diğerleri, 2019; Erten, 2020; Kozikoğlu ve Özcanlı, 2020); öğretim programlarının değerlendirildiği (Belet Boyacı ve Güner Özer, 2019; Kurudayığlu ve Soysal, 2018; Kayhan ve diğerleri, 2019; Tuğluk ve Özkan, 2019); öğrencilerin bu beceriler temelindeki düzey ve algilarının incelendiği (Nacaroğlu, 2020; Alkış, 2020; Öztermiyeci, 2019; Koçak ve Göksu, 2020; Zeybek, 2015; Göktepe Yıldız, 2020) çalışmaların olduğu görülmektedir. Alanyazın incelemelerinde grafik tasarımı bölümü öğretim programlarında yer alan öğrenme çıktılarını 21. yüzyıl becerileri temelinde bütünsel olarak inceleyen bir araştırmaya rastlanmamıştır. Bu araştırmada grafik tasarım bölümü öğretim programlarında yer alan öğrenme çıktılarının geliştirmeyi amaçladığ 21. yüzyıl becerileri temelinde nasıl bir dağılım gösterdiğini ve bu becerilerin programlarda hangi kapsamda kullanıldığını incelemek amaçlanmaktadır. Araştırmanın amacı doğrultusunda, aşağıdaki soruların cevabı aranmiştır:

1. Grafik tasarım bölümü öğretim programlarında yer alan öğrenme çıktıları geliştirmeyi amaçladığı 21. yüzyıl becerisi temelinde nasıl bir dağ̆lım göstermektedir?

2. Grafik tasarım bölümü öğretim programlarında yer alan öğrenme çıktılarının geliştirmeyi amaçladığ 21. yüzyıl becerileri hangi kapsamda kullanılmaktadır?

\section{Yöntem}

\subsection{Araştırmanın Modeli}

Bu araştırmada Türkiye'de grafik tasarımı bölümlerinde yürürlükte olan öğretim programlarındaki öğrenme çıtılarının 21. yüzyıl becerileri temelinde incelenmesi amaçlanmaktadır. Araştırma amaçları doğrultusunda, çalışma grubuna dâhil edilen öğrenme çıktıları üzerinde 21. yüzyıl becerileri kapsamında bir incelemenin yürütülmesi gerekmektedir. Bu nedenle araştırmada nitel araştırma yöntemlerinden biri olan doküman inceleme yöntemi benimsenmiştir. Scott ve Marshall'a (2015) göre, doküman incelemesi bireysel ya da resmi dokümanların 
araştırma materyali olarak kullanılmasıdır. Bu araştırmada 2020 yılı itibariyle Yükseköğretim Kurulu (YÖK) web sayfasında yer alan üniversitelerden aktif olan ve kurumsal web sayfalarından öğretim programlarına ulaşılabilen 20 grafik tasarımı bölümüne ait toplam 292 öğretim programı çıktısı incelenmiş ve çözümlenmiştir. Bu açıdan araştırmada doküman incelemesi yöntemini kullanmanın uygun olduğu düşünülmüştür.

\section{2. Çalışma Grubu}

Araştırma kapsamında öğrenme çıktılarına ulaşılan 20 üniversitenin tamamı için bu işlem gerçekleştirilmiştir. Araştırma kapsamında öğretim programları incelen 20 üniversiteden toplam 292 öğrenme çıktısı aşağıda görüldüğü gibi listelenmiştir.

\section{Tablo 1}

Araştırmanın Çalışma Kapsamına Dâhil Edilen Üniversite ve Incelenen Öğrenme Çıktılarının Listesi

\begin{tabular}{lc}
\hline Üniversitenin Adı & İncelenen Ögrenme Ç1ktısı Sayısı \\
\hline Akdeniz Üniversitesi & 13 \\
Anadolu Üniversitesi & 15 \\
Atatürk Üniversitesi & 5 \\
Onsekiz Mart Üniversitesi & 17 \\
Çukurova Üniversitesi & 20 \\
Dokuz Eylül Üniversitesi & 17 \\
Hacettepe Üniversitesi & 15 \\
İnönü Grafik & 15 \\
Karabük Üniversitesi & 12 \\
Kastamonu Üniversitesi & 14 \\
Kocaeli Üniversitesi & 7 \\
Dumlupınar Üniversitesi & 13 \\
Mersin Üniversitesi & 25 \\
Muğla Sitk1 Koçman Üniversitesi & 12 \\
Ondokuz Mayis Üniversitesi & 16 \\
Ordu Üniversitesi & 15 \\
Selçuk Üniversitesi & 20 \\
Cumhuriyet Üniversitesi & 8 \\
Trakya Üniversitesi & 18 \\
Yalova Üniversitesi & 15 \\
\hline Toplam & 292 \\
\hline
\end{tabular}

\subsection{Verilerin Toplanması}

Araştırmada Yükseköğretim Kurulu'nun resmî web sayfasında yer alan üniversiteler listesinden Türkiye'deki devlet üniversitelerinin resmî web sayfalarına ulaşılmıştır. Ulaşılan her üniversitenin resmî web sayfasından grafik tasarımı bölümü aktif olan üniversitelerin listesi çıkartılmıştır. İncelemede Türkiye'de grafik tasarım bölümünde aktif olarak eğitim öğretime devam eden toplam 25 üniversite olduğu belirlenmiştir. Bu süreçte 5 üniversitenin Bologna bilgi paketinden öğrenme çıktılarına yönelik bilgilere ulaşılamamıştır. Araştırma kapsamında öğretim programı çıktılarına ulaşılan her bir üniversite için bir word dosyası oluşturulmuştur. Her bir word dosyasına ilgili üniversitenin adı verilerek Bologna bilgi paketinde yer alan öğrenme çıktıları listelenmiştir.

\subsection{Veri Analizi}

Araştırmanın veri analizi sürecinde tekrara dayalı okuma, açık kodlama ve sürekli karşılaştırma adımlarının uygulandığı ayrıntılı bir analiz süreci takip edilmiştir. Çalışma kapsamına dâhil edilen her üniversite için ayrı olarak hazırlanan öğrenme çıktılarının kayıtlı olduğu elektronik dokümanlar Max QDA programına yüklenmiştir. Tekrara dayalı okuma süreci öğrenme çıktılarının hangi 21. yüzyıl becerisi ya da becerileri ile ilgili olduğu temelinde gerçekleştirilmiştir. Açık kodlama aşamasında her bir öğrenme çıktısına, "Bu öğrenme çıktısına erişmiş olan bir öğrencinin hangi becerisinin gelişmesi olasıdır? Öğrenme çıktısı öğrencide hangi beceriyi geliştirmeyi amaçlamaktadır?" sorusu yönlendirilmiştir. Analiz sürecinde öğrenme çıktılarının kodlanmasında temele alınan beceriler, P21'deki 21. yüzyıl becerileri sınıflamasına dayanmaktadır. Bu sınıflamada yer alan tüm becerilere ilişkin olarak alan yazındaki kaynaklar taranmış ve her becerinin tanım ve özellikleri maddeler halinde yazılmıştır. Araştırmanın analizi sürecinde becerilerin tanımları temele alınmıştır. Araştırmanın analizinde kullanılan beceri tanımları Tablo 2'de görüldüğü gibidir. Öğrenme çıtıları geliştirmeyi amaçladığına karar verilen beceri ile kodlanmıştır. Bu işlem 292 öğrenme çıktısının tamamı için uygulanmıştır. Analizin ardından ulaşılan sonuçlar betimleyici istatistiklerden yararlanılarak özetlenmiştir. 


\section{Tablo 2}

\section{Analiz Kapsamında Kodlama Sürecinde Kullanılan 21. Yüzyıl Becerilerinin Kapsamı}

\begin{tabular}{|c|c|}
\hline $\begin{array}{l}\text { Yaraticılik ve } \\
\text { İnovasyon }\end{array}$ & $\begin{array}{l}\text { Yaratıcı Düşünme } \\
\text { Çeşitli yaratıcı düşünme tekniklerini uygulamak. Yeni ve değerli fikirler yaratmak. Yaratıcılığa dayalı çabalarını } \\
\text { geliştirmek ve en üst düzeye çıkarmak için kendi fikirlerini detaylandırmak, rafine etmek, analiz etmek ve } \\
\text { değerlendirmek. } \\
\text { Başkalarıyla Yaratıcı Olarak Çalışma } \\
\text { Yeni fikirleri geliştirmek, uygulamak ve diğerleriyle bu çerçevede etkili olarak iletişim kurmak. Yeni ve farklı bakış } \\
\text { açılarına açık ve duyarlı olmak; grup girdisini ve geri bildirimi çalışmaya dâhil etmek. Çalışmada özgünlük ve } \\
\text { yaratıcılık göstermek ve yeni fikirlerin benimsenmesinde gerçek dünya sınırlarını idrak etmek. Başarısızlığı, } \\
\text { öğrenmek için bir firsat olarak görmek. Yaratıcılığın ve yeniliğin küçük başarıların ve sık sık yapılan hataların uzun } \\
\text { vadeli, döngüsel bir süreci olduğunu anlamak } \\
\text { İnovasyon } \\
\text { Yeniliğin gerçekleşeceği alana somut ve yararlı bir katkı sağlamak için yaratıcı fikirler üzerinde hareket etmek. }\end{array}$ \\
\hline $\begin{array}{l}\text { Eleştirel } \\
\text { düşünme ve } \\
\text { Problem Çözme }\end{array}$ & $\begin{array}{l}\text { Etkili olarak akıl yürütmek } \\
\text { Duruma uygun olarak çeşitli akıl yürütme türlerini (tümevarımlı, tümdengelimli, vb.) kullanmak } \\
\text { Düşünme sistemlerini kullanma } \\
\text { Karmaşık sistemlerde genel sonuçlar üretmek için bir bütünün parçalarının birbirleriyle nasıl etkileşime girdiğini } \\
\text { analiz etmek } \\
\text { Yargıda Bulunmak ve Karar vermek } \\
\text { Kanıtları, argümanları, iddiaları ve inançları etkili bir şekilde analiz etmek ve değerlendirmek. Başlıca alternatif } \\
\text { bakış açılarını analiz etmek ve değerlendirmek. Bilgi ve argümanlar arasında sentez yapmak ve bağlantı kurmak. En } \\
\text { iyi analize dayalı olarak bilgileri yorumlamak ve sonuçlar çıkartmak. Öğrenme deneyimleri ve süreçleri hakkında } \\
\text { eleştirel bir şekilde düşünmek. } \\
\text { Problem çözmek } \\
\text { Hem geleneksel hem de yenilikçi yollarla farklı türde aşina olunmayan problemleri çözmek. Çeşitli bakış açılarını } \\
\text { açıklığa kavuşturan ve daha iyi çözümlere götüren önemli soruları belirlemek. }\end{array}$ \\
\hline $\begin{array}{l}\text { İletişim ve } \\
\text { İşbirliği }\end{array}$ & $\begin{array}{l}\text { Açık İletişim Kurma } \\
\text { Çeşitli biçim ve bağlamlarda sözlü, yazılı ve sözsüz iletişim becerilerini kullanarak düşünce ve fikirleri etkili bir } \\
\text { şekilde ifade etmek. } \\
\text { Bilgi, değerler, tutumlar ve niyetler dâhil olmak üzere anlamı deşifre etmek için etkili bir şekilde dinlemek. } \\
\text { İletişimi çeşitli amaçlar için kullanmak. } \\
\text { Birden çok medya ve teknolojiden yararlanmak. Bunların etkinliğini önceden nasıl değerlendireceğini ve etkilerini } \\
\text { değerlendirmeyi öğrenmek. } \\
\text { Çeşitli ortamlarda (çok dilli dâhil) etkili bir şekilde iletişim kurmak. } \\
\text { Birden çok medya ve teknolojiden yararlanmak. Bunların etkinliğini önceden nasıl değerlendireceğini ve etkilerini } \\
\text { nasıl değerlendireceğini öğrenmek. } \\
\text { Çeşitli ortamlarda (çok dilli olanlar dâhil) etkili bir şekilde iletişim kurmak. } \\
\text { Iş̧irliği Yapmak } \\
\text { Çeşitli ekiplerle etkili ve saygılı bir şekilde çalışabilme beceri göstermek } \\
\text { Ortak bir hedefe ulaşılmasına yardımcı olmak için esnek ve istekli olmak } \\
\text { İşbirliğine dayalı çalışmalarda sorumluluk üstlenmek ve her ekip üyesinin bireysel katkılarına değer vermek. }\end{array}$ \\
\hline $\begin{array}{l}\text { Bilgi ve Medya } \\
\text { Teknolojileri }\end{array}$ & $\begin{array}{l}\text { Bilgi Okuryazarlığı } \\
\text { Bilgiye Erişim ve Değerlendirme } \\
\text { Bilgiye verimli ve etkili bir şekilde erişmek } \\
\text { Bilgileri eleştirel ve yetkin bir şekilde değerlendirmek } \\
\text { Bilgiyi Kullanım ve Yönetim } \\
\text { Eldeki sorun veya sorun için bilgileri doğru ve yaratıcı bir şekilde kullanmak } \\
\text { Çok çeşitli kaynaklardan bilgi akışını yönetmek } \\
\text { Bilgiye erişim ve bilgi kullanımı ile ilgili etik / yasal konular hakkında temel bir anlayış geliştirmek. } \\
\text { Medya Okur Yazarlığı } \\
\text { Medyayı Analiz Etmek. } \\
\text { Medya mesajlarının nasıll ve neden oluşturulduğunu ve hangi amaçlarla yapıldığını anlamak. } \\
\text { Bireylerin mesajları nasıl farklı şekilde yorumladığını, değerlerin ve bakış açılarının nasıll dâhil edildiğini veya } \\
\text { dışlandığını ve medyanın inançları ve davranışları nasıl etkileyebileceğini incelemek. } \\
\text { Medyaya erişim ve kullanımla ilgili yasal konularda etik açıdan temel bir anlayış geliştirmek. } \\
\text { Medya Ürünleri Oluşturmak } \\
\text { En uygun medya oluşturma araçlarını, özelliklerini ve kuralları anlamak ve kullanmak. } \\
\text { Çeşitli, çok kültürlü ortamlarda en uygun ifadeleri ve yorumları anlamak ve etkili bir şekilde kullanmak. } \\
\text { BİT (Bilgi, İletişim ve Teknoloji) Okuryazarlık } \\
\text { Teknolojiyi Etkili Uygulama } \\
\text { Bilgiyi araştırmak, düzenlemek, değerlendirmek ve iletmek için bir araç olarak teknolojiyi kullanmak. } \\
\text { Bilgi ekonomisinde başarılı bir şekilde çalışmak için bilgiye erişmek, yönetmek, entegre etmek, değerlendirmek ve } \\
\text { oluşturmak için dijital teknolojiler iletişim / ağ oluşturma araçlarını ve sosyal ağları uygun şekilde kullanmak. } \\
\text { Bilgi teknolojilerine erişim ve kullanımla ilgili etik / yasal konular hakkında temel bir anlayış geliştirmek. }\end{array}$ \\
\hline $\begin{array}{l}\text { Yaşam ve } \\
\text { Kariyer } \\
\text { Becerileri }\end{array}$ & $\begin{array}{l}\text { Esneklik ve Uyarlanabilirlik } \\
\text { Değişime Uyum Sağlamak } \\
\text { Çeşitli rollere, iş sorumluluklarına, programlara ve bağlamlara uyum sağlamak } \\
\text { Belirsizlik ve değişen önceliklerin olduğu bir ortamda etkili bir şekilde çalışmak } \\
\text { Esnek olmak } \\
\text { Geri bildirimi etkili bir şekilde dâhil etmek } \\
\text { Övgü, aksaklıklar ve eleştirilerle olumlu bir şekilde ilgilenmek } \\
\text { Özellikle çok kültürlü ortamlarda işlenebilir çözümlere ulaşmak için farklı görüş ve inançları anlamak, müzakere } \\
\text { etmek ve dengelemek. }\end{array}$ \\
\hline
\end{tabular}


Tablo 2'nin devamı

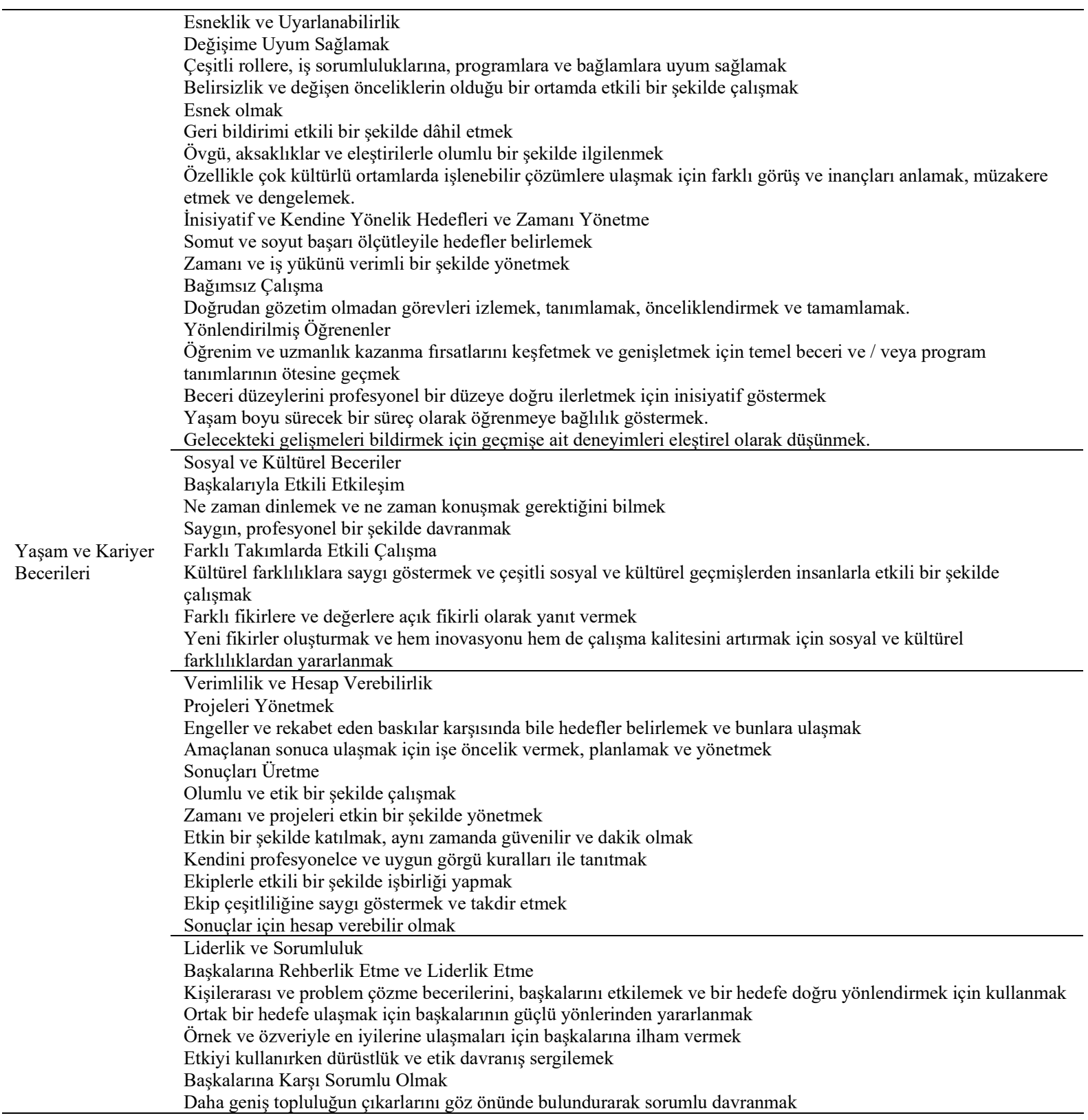

Analizin ikinci aşamasında öğrenme çıktıları geliştirmeyi amaçladığı 21. yüzyıl becerileri temelinde sınıflandırılarak her bir beceri için ayrı bir elektronik belge oluşturulmuştur. Bu sayede aynı beceriyi geliştirmeyi amaçlayan etkinlikleri alt alta görmek mümkün olmuştur. Bu süreçte beceriler temelinde sınıflanan etkinlikler, tekrara dayalı olarak okunarak ve sınıflandırmadaki tutarlılık kontrol edilmiştir. Ardından aynı beceriyi geliştirmeyi amaçlayan etkinliklere "Bu öğrenme çıktısının geliştirmeyi amaçladığı becerinin hangi yönüne odaklanılmıştır?" sorusu yönlendirilmiştir. Analizin bu aşamasında incelenen her öğrenme çıktısı yukarıda ifade edilen soru temelinde kodlanmıştır. Becerinin öğrenme çıktısındaki yönü temelinde kodlara göre yapılan sınıflama kümeleri üzerinde, sürekli karşılaştırma yöntemi uygulanmıştır. Bu aşamada sınıflama kümeleri arasında gerekli görülen birleştirme, ayırma ve yeniden isimlendirme işlemleri gerçekleştirilmiştir. Tekrarlı okumaların ardından kategoriler değişmeyen bir duruma gelinceye kadar bu işlem sürdürülmüştür.

\subsection{Geçerlik ve Güvenirlik Çalıșmaları}

Nitel araştırma yönteminin benimsendiği bu araştırmada geçerlilik ve güvenirlik çalışmaları kapsamında aşağıdaki çalışmalar yürütülmüştür. Nitel araştırmalarda geçerlilik ve güvenirlik çalışmalarından biri olan inandırıcılık, toplanan verilerin doğruluğu ve inandırıcılığ 2020 yılında Türkiye'de aktif öğrencisi bulunana devlet üniversitelerinin grafik tasarımı bölümlerinin resmî web sayfalarında Bologna bilgi paketinde yer alan öğretim programlarındaki öğrenme çıktıları incelenmiştir. Araştırma kapsamında çözümlenen veriler, resmî web sayfalarında yayınlandığı şekliyle alınmıştır. Bu açıdan araştırmada 
incelenen verilerin inandırıcılık gerekliliğini sağladığı söylenebilir. Nitel araştırmalarda inandırıcılığı sağlamanın bir diğer yolu çalışma grubunun sayı ve özellikleri, nasıl seçildikleri, araştırmada kullanılan veri toplama araçları ve analiz tekniklerinin ayrıntılı biçimde açıklanmasıdır (Creswell ve Miller, 2000). Sözü edilen gereklilik kapsamında araştırmanın yöntem başlığı altında yukarıda sözü geçen bilgiler ayrıntılı biçimde açıklanmıştır. Araştırma evreninin tamamına ulaşıldığı bu araştırma inandırıcılığın diğer bir gereğini de karşılamaktadır. Nitel araştırmalarda güvenirlik gerekliliklerinden biri kodlayıcılar arası güvenirliktir. Bu gereklilik kapsamında çözümlemeler iki araştırmacı tarafından gerçekleştirilmiştir. Her iki araştırmacı da veri çözümlenmesinde alanyazın incelemelerine dayalı olarak geliştirilen ve Tablo 2'de ifade edilen açıklamalardan yararlanmıştır. Araştırmacılardan biri eğitim programları ve öğretim, diğeri grafik tasarımı alanında uzman öğretim üyesidir. Kodlanan her bir öğrenme çıtısı üzerinde uzlaşmaya varıncaya kadar değerlendirmeler sürdürülmüştür. Ayrıca bulguların sunumunda verilen kodların açık ve net bir şekilde ifade edilmesi ve doğrudan alıntılarla desteklenmesi yoluyla da çalışmanın geçerliliği ve güvenilirliği artırılmaya çalışılmıştır.

\section{Bulgular}

\subsection{Araştırmanın Birinci Alt Problemine Yönelik Bulgular}

Bu başlık altında araştırmanın birinci alt problemi olan "Grafik tasarım bölümü öğrenme çıktılarının 21.yüzyıl becerileri temelinde nasıl bir dağılım göstermektedir?” sorusunun cevabı aranmıştır. Araştırma problemi temelinde ulaşılan bulgular Tablo 3'de görüldüğü gibidir.

Tablo 3

Grafik Tasarım Bölümü Öğrenme Çıktılarının 21.Yüzyıl Becerileri Temelinde Analizi

\begin{tabular}{|c|c|c|c|c|}
\hline \multirow{14}{*}{$\begin{array}{l}21 . y u ̈ z y 11 \\
\text { becerileri }\end{array}$} & & & $\mathrm{f}$ & $\%$ \\
\hline & Öğrenme ve inovasyon becerileri & İletişim ve işbirliği & 46 & 13,6 \\
\hline & & Eleştirel düşünme ve problem çözme & 79 & 23,3 \\
\hline & & Yaratıcılık ve inovasyon & 50 & 14,8 \\
\hline & Toplam & & 175 & 51,7 \\
\hline & Yaşam ve kariyer becerileri & Liderlik ve sorumluluk & 39 & 11,5 \\
\hline & & Sosyal ve kültürlerarası beceriler & 2 & 0,6 \\
\hline & & Girişim ve kendini yönlendirme & 26 & 7,7 \\
\hline & & Esneklik ve uyum yeteneği & 6 & 1,8 \\
\hline & Toplam & & 73 & 21,6 \\
\hline & Bilgi medya teknoloji becerileri & Bilgi iletişim teknolojileri yeterliliği & 46 & 13,6 \\
\hline & & Medya okuryazarlığı & 0 & 0 \\
\hline & & Bilgi okuryazarlığ & 5 & 1,5 \\
\hline & Toplam & & 51 & 15,1 \\
\hline \multirow[t]{3}{*}{ Diğer } & Diğer Öğrenme Çıktıları & Genel Kültür Bilgisi & 4 & 1,2 \\
\hline & & Mesleki Bilgi & 35 & 10,3 \\
\hline & Toplam & & 39 & 11,5 \\
\hline Toplam & & & 339 & 100 \\
\hline
\end{tabular}

Araştırma, öğrenme çıktılarının en fazla (\%51.7) geliştirmeyi amaçladığı becerinin "öğrenme ve inovasyon becerileri" olduğunu göstermektedir. İncelenen programlarda toplam 175 öğrenme çıktısı bu beceriyi geliştirmeyi amaçlamaktadır.“Öğrenme ve inovasyon becerileri”nin alt beceri alanlarının kendi aralarında gösterdiği dağılım incelendiğinde ise sırasıyla eleştirel düşünme ve problem çözme (\%23.3), yaratıcılık ve inovasyon $(\% 14.8)$, iletişim ve işbirliği (\%13.6) becerilerinin yer aldığ 1 görülmektedir. Araştırma "yaşam ve kariyer becerileri"nin ikinci sırada yer aldığını göstermektedir. Toplam 73 öğrenme çıktısı bu alanda yer alan becerileri geliştirmeyi amaçlamaktadır. "Yaşam ve kariyer becerileri" liderlik ve sorumluluk, sosyal ve kültürlerarası beceriler, girişim ve kendini yönlendirme, esneklik ve uyum yeteneği olmak üzere dört alt beceri kapsamında ele alınmaktadır. Grafik tasarım bölümü öğretim programı öğrenme çıktılarının bu alt beceri alanları temelinde gösterdiği dağılım incelendiğinde öğrenme çıtılarının neredeyse tamamının liderlik ve sorumluluk (\%11.5), girişim ve kendini yönlendirme becerilerini (\%7.7) geliştirmeyi amaçladığ 1 görülmektedir. Buna karşın sosyal ve kültürlerarası beceriler (\%0.6) ile esneklik ve uyum yeteneği becerilerinin (\%1.8) oldukça düșük bir orana sahip olduğu görülmektedir.

Tablo 2 incelendiğinde "bilgi ve medya teknolojileri becerileri”nin üçüncü sırada yer aldığı görülmektedir. Bu beceri alanı 15.1'lik bir orana sahiptir. Araştırmada bu beceri alanında en fazla bilgi iletişim teknolojileri alt yeterliliğine (\%13.6) ağırlık verildiği görülmektedir. Medya okuyazarlığını geliştirmeyi amaçlayan hiçbir öğrenme çıtısına rastlanılmamıştır. Bilgi okuryazarlığını geliştirmeye yönelik öğrenme çıktısı oranının ise \%1.5 olduğu görülmüştür. Araştırmada grafik tasarım öğretim programlarında genel kültür bilgisi ve mesleki bilgiye odaklı olduğu belirlenen öğrenme çıktıları "diğer öğrenme çıktıları" başlığı altında incelenmiştir. Bu başlık altında yer alan öğrenme çıktılarının büyük bir bölümünün meslek bilgisi (\%10.3) ile ilgili olduğu, çok düşük bir oranda da genel kültür (\%1.2) ile ilgili öğrenme çıktıları olduğu görülmüştür. Tablo 4.’te araştırma kapsamında yapılan analize ilişkin örnek öğrenme çıktısı alıntıları yer almaktadır. 


\section{Tablo 4}

Grafik Tasarım Bölümü Öğrenme Çıktılarına Yönelik Inceleme Temelinde Örnek Alıntılar

\begin{tabular}{|c|c|c|}
\hline \multicolumn{2}{|c|}{ 21. yüzy1l becerileri } & Alintilar \\
\hline \multirow[b]{3}{*}{$\begin{array}{l}\text { Öğrenme ve } \\
\text { inovasyon } \\
\text { becerileri }\end{array}$} & İletişim ve işbirliği & $\begin{array}{l}\text { Sanat Çalışmalarını topluma anlatabilecek iletişim becerisine sahiptir (Mersin Ü./G.S.F./Grafik } \\
\text { Tasarım Bölümü) } \\
\text { Bağımsız olarak veya grup içinde uyumlu ve üretken olarak çalışır bu çalışmaları toplumla } \\
\text { paylaşır (Hacettepe Ü./G.S.F./Grafik Tasarım Bölümü) }\end{array}$ \\
\hline & $\begin{array}{l}\text { Eleştirel düşünme } \\
\text { ve problem çözme }\end{array}$ & $\begin{array}{l}\text { Tasarım problemi hakkında sorgulayıcılı̆̆ını arttırarak eleştirel düşünebilme yetisi kazanır } \\
\text { (Akdeniz Ü./G.S.F./Grafik Tasarım Bölümü) } \\
\text { Alanı ile ilgili uygulamalarda öngörülmeyen durumlarla karşılaştığında çözüm üretebilmek } \\
\text { (Yalova Ü./G.S.F./Grafik Tasarım Bölümü) }\end{array}$ \\
\hline & $\begin{array}{l}\text { Yaratıcılık ve } \\
\text { inovasyon }\end{array}$ & $\begin{array}{l}\text { Sanat ve tasarımın temel ölçütlerini kullanarak, görsel iletişim sorunları için yaratıcı, özgün, } \\
\text { ekonomik, estetik alternatif taslaklar hazırlama (Çukurova Ü./G.S.F./Grafik Tasarım Bölümü). } \\
\text { Yaratıcılık ve becerisini kullanarak nitelikli grafik tasarım ürünleri geliştirir (Hacettepe } \\
\text { Ü./G.S.F./Grafik Tasarım Bölümü). } \\
\text { İnteraktif dijital uygulama tekniklerini sanat felsefesi ile ve grafik tasarım temelleri ile birleştirir } \\
\text { ve teknikleri harmanlayarak kullanır (Yalova Ü./G.S.F./Grafik Tasarım Bölümü) }\end{array}$ \\
\hline \multirow{5}{*}{$\begin{array}{l}\text { Yaşam ve } \\
\text { kariyer } \\
\text { becerileri }\end{array}$} & $\begin{array}{l}\text { Liderlik ve } \\
\text { sorumluluk }\end{array}$ & $\begin{array}{l}\text { Toplumsal sorumluluk bilinci ile yaşadığı sosyal çevre için proje ve etkinlikler düzenleyebilme } \\
\text { ve bunları uygulayabilme (Mersin Ü./G.S.F./Grafik Tasarım Bölümü). } \\
\text { Fikir ve sanat eserleri hakkında mesleki ve etik sorumluluk bilincine sahip olabilme (Anadolu } \\
\text { Ü./G.S.F./Grafik Tasarım Bölümü). }\end{array}$ \\
\hline & Sosyal ve & Sosyal kültürel ve toplumsal sorumlulukları kavrama, benimseme ve uygulayabilme (Kastamonu \\
\hline & beceriler & $\begin{array}{l}\text { Meslek yaşamında kendini sürekli geliştirebilecek, yeniliklere açık, ekip çalışmasına uygun, } \\
\text { sorumluluklarının farkında, sosyal becerileri gelişmiş davranış özellikleri kazanırlar (Ondokuz } \\
\text { Mayıs Ü./G.S.F./Grafik Tasarım Bölümü). }\end{array}$ \\
\hline & $\begin{array}{l}\text { Girişim ve kendini } \\
\text { yönlendirme }\end{array}$ & $\begin{array}{l}\text { Zamanlama, sabır, iş bilinci, uzlaşmacılık, özgüven, ikna yeteneği ve düzenlilik becerilerine } \\
\text { sahip olabilmek (Dokuz Eylül Ü./G.S.F./Grafik Tasarım Bölümü). } \\
\text { Öğrenmeyi öğrenebilmek ve yönetebilmek (Kocaeli Ü./G.S.F./Grafik Tasarım Bölümü). }\end{array}$ \\
\hline & $\begin{array}{l}\text { Esneklik ve uyum } \\
\text { yeteneği }\end{array}$ & $\begin{array}{l}\text { Değişen ve gelişen toplum dinamiklerine uyum sağlamak (Onsekiz Mart Ü./G.S.F./Grafik } \\
\text { Tasarım Bölümü). } \\
\text { Çağın getirdiği teknolojik yeniliklere ayak uydurmak (Onsekiz Mart Ü./G.S.F./Grafik Tasarım } \\
\text { Bölümü). }\end{array}$ \\
\hline \multirow{3}{*}{$\begin{array}{l}\text { Bilgi medya } \\
\text { teknoloji } \\
\text { becerileri }\end{array}$} & $\begin{array}{l}\text { Bilgi iletişim } \\
\text { teknolojileri } \\
\text { yeterliliği }\end{array}$ & $\begin{array}{l}\text { Grafik tasarımı alanıyla ilgili teknolojik olanakları, araç ve gereçleri yetkin biçimde kullanır } \\
\text { (Karabük Ü./G.S.F./Grafik Tasarım Bölümü). } \\
\text { Çağın gerektirdiği gelişmiş donanımı yetkin şekilde kullanır (Selçuk Ü./G.S.F./Grafik Tasarım } \\
\text { Bölümü). }\end{array}$ \\
\hline & $\begin{array}{l}\text { Medya } \\
\text { okuryazarlığı }\end{array}$ & . \\
\hline & Bilgi okuryazarlı̆̆ 1 & $\begin{array}{l}\text { Görsel iletişimin teknolojik gelişmelerine paralel olarak, uygulamalarında kullanabilecek düzeyde } \\
\text { yenilikleri takip etme ve değerlendirme (Çukurova Ü./G.S.F./Grafik Tasarım Bölümü). } \\
\text { Bilgiye kolay ulaşabilme (Hacettepe Ü./G.S.F./Grafik Tasarım Bölümü) }\end{array}$ \\
\hline \multirow{2}{*}{$\begin{array}{l}\text { Diğger } \\
\text { Öğrenme } \\
\text { Çıktıları }\end{array}$} & Genel Kültür & $\begin{array}{l}\text { Entelektüel bilgi birikimine sahip olabilmek (Dokuz Eylül Ü./G.S.F./Grafik Tasarım Bölümü). } \\
\text { Yeterli seviyede genel kültüre sahip olmak (anadil, yabancı dil, tarih vb) (Dumlupınar } \\
\text { Ü./G.S.F./Grafik Tasarım Bölümü). }\end{array}$ \\
\hline & Mesleki Bilgi & $\begin{array}{l}\text { Grafik sanatı, grafik sanatçıları ve sanat eserleri hakkında bilgiye sahiptir (Trakya } \\
\text { Ü./G.S.F./Grafik Tasarım Bölümü). } \\
\text { Sanat kültürü ve estetik konularına ilişkin bilgiye sahiptir (Mersin Ü./G.S.F./Grafik Tasarım } \\
\text { Bölümü). }\end{array}$ \\
\hline
\end{tabular}

\subsection{Araştırmanın İkinci Alt Problemine Yönelik Bulgular}

Bu başlık altında araştırmanın ikinci alt problemi olan "Grafik tasarım bölümü öğretim programlarında yer alan öğrenme çıktılarının geliştirmeyi amaçladığı 21. yüzyıl becerileri hangi kapsamda kullanılmaktadır?” sorusunun cevabı aranmıştır. Araştırma problemi temelinde ulaşılan bulgular Tablo 5.'de görüldüğü gibidir. Bu inceleme öğretim programlarında 21. yüzyıl becerilerinden hangi oranda etkin bir şekilde faydalanıldığını, hangi alt boyutlarına ağırlık verilirken hangi alt boyutlarının açıkta bırakıldığını görebilmeyi mümkün kılmaktadır.

Tablo 5

Grafik Tasarım Bölümü Öğrenme Çıktılarında 21. Yüzyıl Becerileri

\begin{tabular}{ll}
\hline 21.Yüzyıl Becerisi & İçerik \\
\hline $\begin{array}{l}\text { Öğrenme ve inovasyon becerileri/ Eleştirel düşünme ve } \\
\text { problem çözme }\end{array}$ & $\begin{array}{l}\text { *uygulamaya yönelik problemler *alana yönelik problemler *yerel ve küresel } \\
\text { problemler *sanat ve tasarım problemleri }\end{array}$ \\
\hline & $\begin{array}{l}* \text { alanıla ilgili araştırma sonuçları, problem, çözüm önerileri, düşünce, tasarım } \\
\text { ve projeleri meslektaş, işveren, hizmet sunduğu kişiler, uzman ya da uzman }\end{array}$ \\
ömayan kişilere, amacina uygun bir biçimde görsel, yazılı ve sözlü olarak \\
Öğrenme ve inovasyon becerileri/ İletişim ve işbirliği ve etkin bir biçimde kullanma özgüven ve becerilerini geliştirme \\
$\begin{array}{l}* \text { grupla uyumlu, üretken olarak projelerde uyumlu, üretken çalışma, } \\
\text { sorumluluk alma, inisiyatif alma }\end{array}$
\end{tabular}


Tablo 5 ' in devamı

\begin{tabular}{|c|c|}
\hline $\begin{array}{l}\text { Öğrenme ve inovasyon becerileri/ Yaratıcılık ve } \\
\text { İnovasyon Becerileri }\end{array}$ & $\begin{array}{l}\text { *probleme dayalı yaratıcılık *araştırmaya dayalı olarak, değerlere, objeye, } \\
\text { tasarım problemlerine, tasarım gereksinimlerine dayalı olarak yaratıcı ürünler } \\
\text { ortaya koyma }\end{array}$ \\
\hline Yaşam ve kariyer becerileri/ Liderlik ve Sorumluluk & $\begin{array}{l}\text { *çevreye ve insana karşı duyarlı ve sorumlu davranma *ulusal ve evrensel } \\
\text { sorunlara duyarlı olma } \\
\text { *toplumsal ve sosyal sorumluluk bilinciyle hareket etme } \\
\text { *tasarım sürecinde ulusal ve uluslararası değerlerin farkında olma } \\
\text { *mesleğin etik ve hukuki değerlerine itina gösterme } \\
\text { *yasal düzenleme ve işlemler konusunda bilgi sahibi olma } \\
\text { *demokrasi insan hakları bilimsel, toplumsal, kültürel değerlere, mesleki ve } \\
\text { etik ilkelere uygun olarak hareket etme }\end{array}$ \\
\hline $\begin{array}{l}\text { Yaşam ve kariyer becerileri/ Sosyal ve kültürlerarası } \\
\text { beceriler }\end{array}$ & $\begin{array}{l}\text { *sosyal kültürel ve toplumsal sorumlulukları kavrama, benimseme ve } \\
\text { uygulayabilme }\end{array}$ \\
\hline $\begin{array}{l}\text { Yaşam ve kariyer becerileri / Girişim ve Kendini } \\
\text { Yönlendirme }\end{array}$ & $\begin{array}{l}\text { *yaşam boyu öğrenme *zamanı etkin olarak kullanma *öğrenme } \\
\text { gereksinimlerini belirleme *disiplinli çalışma *planlama ve yönetme } \\
\text { *öğrenmeyi öğrenme ve yönetme becerileri }\end{array}$ \\
\hline $\begin{array}{l}\text { Yaşam ve kariyer becerileri/ Esneklik ve Uyum } \\
\text { Becerilerine }\end{array}$ & *değişen ve gelişen toplumsal dinamiklere uyum sağlama \\
\hline $\begin{array}{l}\text { Bilgi medya teknoloji becerileri/ Bilgi İletişim } \\
\text { Teknolojileri Yeterliliği }\end{array}$ & $\begin{array}{l}\text { *grafik tasarımın uygulama alanlarında dijital üretim araçlarını kullanma } \\
\text { konusunda yeterlilik kazanma }\end{array}$ \\
\hline $\begin{array}{l}\text { Bilgi medya teknoloji becerileri/ Bilgi Medya Teknoloji } \\
\text { Becerileri }\end{array}$ & - \\
\hline Bilgi medya teknoloji becerileri/ Bilgi Okuryazarlığ & $\begin{array}{l}\text { *bilgiyi yönetme *bilgiye kolay ulaşma *bilgiyi doğru alanla birleştirebilme } \\
\text { *alanıyla ilgili yenilikleri takip etme }\end{array}$ \\
\hline
\end{tabular}

Tablo 5'de görüldüğü gibi “eleştirel düşünme ve problem çözme becerisi”"ni geliştirmeyi amaçlayan öğrenme çıktılarında ağırlığın problem çözme becerisine verildiği görülmektedir. Bu beceriyi geliştirmeyi amaçlayan öğrenme çıktıları "uygulamaya yönelik problemler", "alana yönelik problemler", "yerel ve küresel problemler", "sanat ve tasarım problemleri” içeriğine sahiptir. "Yaratıcılık ve inovasyon becerileri”"ni geliştirmeyi amaçlayan öğrenme çıktılarının, ağırlıklı olarak "yaratıcı düşünme” becerisine odaklandığı görülmektedir. Öğrenme çıtılarında "yaratıcı düşünme becerisi" "öğrencilerin kuramsal bilgilerini yaratıcı ve özgün bir biçimde uygulamaya dönüştürme” içeriğine sahiptir. Öğrenme çıktılarında öğrencilerden yaratıcı ürün olarak sunum dosyası tasarlamaları, çeşitli grafik ürünler oluşturmaları ya da bir proje yürütmeleri beklenmektedir.

Araştırmada "liderlik ve sorumluluk becerileri”"ni geliştirmeyi amaçlayan öğrenme çıtılarının ağırlıklı olarak "sorumluluk becerisi”ne odaklandığı görülmektedir. Sorumluluk becerisini geliştirmeyi amaçlayan öğrenme çıktılarının, "çevreye ve insanlara karşı duyarlı ve sorumlu davranma", "ulusal ve evrensel meselelere ilgili olma", "sosyal sorumluluk bilinciyle hareket etme", "tasarım sürecinde ulusal ve uluslararası değerlerin farkında olma", "mesleğin etik ve hukuki sorumluluklarına karşı itina gösterme”, "yasal düzenleme ve işlemler konusunda bilgi sahibi olma" içeriğine sahip olduğu görülmektedir.

“Girişim ve kendini yönlendirme becerileri”ni geliştirmeyi amaçlayan öğrenme çıktılarında "kendini yönlendirme becerisi”ne ağılık verildiği görülmektedir. Bu becerinin "yaşam boyu öğrenme”, "zamanı etkin olarak kullanma”, “öğrenme gereksinimlerini belirleme”, "disiplinli çalışma”, "planlama ve yönetme”, "öğrenmeyi öğrenme” içeriği kapsamında ele alındığ 1 görülmektedir. Araştırma, öğrenme çıktılarında “esneklik ve uyum becerileri”ne düşük bir oranda yer verildiğini göstermektedir. Bu beceriyi geliştirmeyi amaçlayan öğrenme çıktılarında ağırlıklı oranın "uyum becerileri”ne ait olduğu görülmektedir. Uyum becerisinin ise "değişen ve gelişen toplumsal dinamiklere uyum sağlama" içeriği kapsamında ele alındığı görülmektedir.

"Bilgi iletişim teknolojileri yeterliliği”nin “grafik tasarımın uygulama alanlarında dijital üretim araçlarını kullanma” içeriği kapsamında ele alındığı görülmektedir. Araştırmada “bilgi medya teknoloji becerileri” içinde yer alan "medya okuryazarlığı" alanında bir öğrenme çıktısına rastlanmamıştır. "Bilgi okuryazarlığı becerisi"nin ise "edindiği bilgiyi yönetme", "bilgiye kolay ulaşma", "bilgiyi doğru alanla birleştirebilme" ve "alanıyla ilgili yenilikleri takip etme" içeriği kapsamında ele alındığı görülmektedir.

\section{Sonuç ve Tartışma}

Grafik tasarım bölümü öğretim programı öğrenme çıktılarının 21. yüzyıl becerileri temelinde gösterdiği dağılımı incelemeyi amaçlayan bu araştırmada Türkiye'de aktif olarak eğitim öğretime devam eden ve kurumsal internet sayfalarından öğretim programı bilgisine ulaşılabilen tüm grafik tasarım bölümlerine ait öğrenme çıtıları incelenmiştir. Araştırma kapsamında 20 üniversiteden toplam 292 öğrenme çıktısı incelenmiştir. İncelenen öğrenme çıktılarının hangi 21. yüzyıl becerisi/becerilerini geliştirmeyi amaçladığ 1 betimsel istatistiklerden yararlanılarak özetlenmesinin yanında söz konusu becerinin hangi içerik kapsamında ele alındığı da çözümlenmiştir. Araştırma bu yönüyle Türkiye'de grafik tasarım bölümlerinin 21. yüzyılın gerekliliklerini karşılama konusundaki yeterliliklerinin bir görünümünü ortaya koymaktadır. Öte yandan araştırma, bu becerilerin 
kapsamlarının da hangi oranda geçerli ve yeterli olarak kullanıldığına yönelik çıkarımlarda bulunma olanağı sunmaktadir.

Üniversitelerin 21.yüzyılın gerektirdiği becerilerde üst yeterliliğe ulaşmış bireylerin yetiştirilmesi misyonunu yerine getirebilmesinde öğrenme çıktılarının anahtar bir öneme sahip olduğu açıktır. Bu bağlamda araştırma bulguları incelendiğinde üniversitelerin grafik tasarım bölümü öğrenme çıktılarında "medya okuryazarlığı" dışında kalan tüm becerilerin geliştirilmesini amaçlayan öğrenme çıktılarının olduğu görülmektedir. "Öğrenme ve inovasyon becerisi" en fazla geliştirilmesi amaçlanan beceridir. Bu beceriyi sırasıyla "yaşam ve kariyer becerileri" ile "bilgi ve iletişim teknolojileri becerileri”" takip etmektedir. İncelenen öğrenme çıktılarında en fazla geliştirilmesi amaçlanan beceri “eleştirel düşünme ve problem çözme becerileri”dir. Toplam 79 öğrenme çıktısının bu beceriyi geliştirmeyi amaçladığı görülmektedir. İkinci sırada yer alan becerinin "yaratıcılık" olduğu görülmektedir. Toplamda 50 öğrenme çıktısının bu beceriyi geliştirmeyi amaçladığı görülmektedir. Bu beceriyi sırasıyla "bilgi ve iletişim teknolojileri yeterliliği” ile "iletişim ve işbirliği becerileri” takip etmektedir. Bu iki beceriyi geliştirmeyi amaçlayan toplam 46 öğrenme çıtısı vardır. Eleştirel düşünme ve problem çözme kapsamında kodlanan öğrenme çıktılarında ağırlıklı olarak problem çözme becerisine yer verildiği görülmektedir. Eleştirel düşünmenin "alanında edindiği bilgi ve becerileri eleştirel bir anlayışla değerlendirir” öğrenme çıktısı ile birkaç üniversitede yer aldığı görülmektedir. "İletişim ve işbirliği becerisi” kapsamında öğrenme çıktılarının tamamına yakınının iletişim becerilerine odaklandığı görülmektedir. "Işsirliği içinde çalışma becerisi”nin ise oldukça düşük oranda yer aldığı görülmektedir. "Liderlik ve sorumluluk becerileri” kapsamında kodlanan öğrenme çıktılarında ağırlığın "sorumluluk becerisi"ne verildiği görülmektedir. "Girişim ve kendini yönlendirme becerisi" ile kodlanan öğrenme çıktılarının ağırlıklı olarak "kendini yönlendirme” kapsamına sahip olduğu görülmektedir. "Esneklik ve uyum becerileri” ile kodlanan öğrenme çıktılarının ağırlıklı olarak uyum becerilerini geliştirmeyi amaçladığı görülmektedir. Grafik tasarımı alanında incelenen öğrenme çıktılarında "bilgi medya teknoloji becerileri” içinde yer alan "medya okuryazarlığı” alanında bir öğrenme çıktısına rastlanmamıştır.

İşbirliği becerilerinin önemi 21. yüzyıl becerileri kadar son dönemlerde eğitim politikası tartışmalarında vurgulanmaktadır (OECD 2013). İşbirliğine dayalı çalışmanın bireysel öğrenme ve bilgi oluşturma üzerinde olumlu bir etkisi olabileceği (O'Donnell ve Hmelo Silver 2013) ifade edilmektedir. İşbirliğine dayalı çalışmalarda sosyal etkileşim olmadan elde edilemeyecek benzersiz sonuçlar elde edilebilmektedir (Sears ve Reagin 2013). Bu nedenle, iyi performans göstermek, yalnızca bilişsel becerilere sahip olmak değil, aynı zamanda akran öğrencilerle işbirliği yapma becerilerine sahip olmak demektir. Grafik tasarım bölümü öğretim programı çıktıları incelendiğinde iletişim ve işbirliği becerisi kapsamında öğrenme çıktılarının tamamına yakınının iletişim becerilerine odaklandığ1 görülmektedir. İşbirliği içinde çalışma becerisinin ise oldukça düşük oranda yer aldığ 1 görülmektedir. İletişim ve işbirliği becerilerinin içeriğine yönelik bu inceleme bir grafik tasarımcı için söz konusu becerilerin profesyonel bir gereklilik olduğunu göstermektedir. İşbirliği halinde çalışma becerisi, grafik tasarım bölümlerinde öğrencilerin yürüttüğü ekip çalışmaları ve ortak projeler ile ileri seviyede geliştirilebilir. Bu beceri, öğrencilerin mezun olduktan sonra tasarımcı olarak adım atacakları profesyonel çalışma ortamlarında son derece önemsenmektedir. Grafik tasarım alanı her geçen gün genişleyen sınırlarıyla farklı alanlarda uzmanlaşmış kişilerin birlikte hareket edebilme yetkinliğine ihtiyaç duyan bir meslek haline gelmektedir. Dolayısıyla bu yetkinliğin öğretim programlarında öğrenme çıktısı olarak net bir biçimde ifade edilmesi, bu konuda ortak bir standardın ve anlayışın oluşturulması için oldukça önemlidir.

Eleştirel düşünme çalışma hayatında önemli kabul edilmektedir (Dwyer ve diğerleri, 2015). Eleştirel düşünme yeteneği, daha etkili karar verme (Park ve Kim, 2009) ve genel iş performansı (Baril ve diğerleri, 1998) ile bağlantılıdır. Eleştirel düşünmenin "alanında edindiği bilgi ve becerileri eleştirel bir anlayışla değerlendirir" öğrenme çıktısı ile birkaç üniversitede yer aldığı görülmektedir. Grafik tasarım öğrencilerinin nitelikli bir tasarımcı olma süreci eleştirel düşünme becerisinin tüm boyutlarının titizlikle planlanmış yükseköğretim uygulamaları ile geliştirilmelidir. Eleştirel düşünme becerisi gelişmiş bir tasarımcı üretim sürecinde üst bir farkındalık ve yaratıcılık gösterebilir. Daha da önemlisi tasarım sürecinin içerdiği aşamalara yönelik takındığı eleştirel ve yansıtıcı tavır öğrenciye giriştiği her tasarım deneyiminden dönüşerek çıkmasının yolunu açacaktır. Grafik tasarımı lisans programlarında eleştirel düşünme becerisinin daha geniş bir anlayışla ele alınması önemli bir gerekliliği oluşturmaktadır. Nitekim öğretim programlarında eleştirel düşünme becerisi içinde değerlendirilebilecek olan diğer beceriler, karar verme, diyalektik düşünme, biçim algısı, argümanstasyon, yorumlama, transfer, gözlem, ilişkilendirme, analiz, değerlendirme, sentez, araştırma, sorgulama ve kavramsal düşünmedir. Ancak öğretim programlarında sistematik bir anlayışın uzağında olduğu gözlenen bu becerilerin, öğrenme çıtılarında daha sistemli bir anlayış içinde ele alınması büyük bir önem taşımaktadır.

İnovasyon bir ülkenin ekonomik kalkınmasının merkezinde, endüstriyel rekabet gücünün en önemli bileşeni ve kişisel kariyer gelişimi için en önemli beceridir (European Commission, 2016). Avrupa Birliği'nin Horizon 2020 planı (European Commission, 2019) somut projelerle endüstriyel inovasyonu teşvik etmeyi ve yaratıcılığ geliştirmeyi amaçlamaktadır. Yaratıcı eğitimin teşviki, gelişmiş ülkelerin rekabet gücünü artırmak için çok önemlidir (Huang ve diğerleri, 2020). Yaratıcı düşünme esneklik, akıcılık (Kassim ve diğerleri, 2014), yenilik ve 
detaylandırmayı içerir. Yaratıcı performans açıkça yaratıcı düşünceyi içerir ve iki ana gösterge temelinde değerlendirilir: özgünlük ve kalite (Montag Smit ve Maertz, 2017). Grafik tasarımı öğretiminde en önce geliştirilmesi gereken becerinin yaratıcılık olduğunu söylemek güç değildir. Yaratıcılık ve inovasyon becerileri kapsamında öğrenme çıktılarında yoğun olarak yaratıcılık becerisinin yer aldığı görülmektedir. Öğrenme çıktılarına yakından bakıldığında öğrencilerden yaratıcı uygulamalar olarak edindikleri kuramsal donanım ve teknik becerileri temel alan özgün, estetik değerlere sahip ve yenilikçi grafik ürünler tasarlamaları veya projeler yürütmeleri beklenmektedir. Fakat diğer yandan yaratıcılı̆̆ın önemli bir boyutunu oluşturan kendi fikirlerini inceleme ve analiz etme gibi öz değerlendirmeye yönelik öğrenme çıktılarına rastlanmamaktadır. Bu durumda yaratıcılık gibi çok sayıda temel becerinin eş zamanlı ya da aşamalı olarak kullanılmasını gerektiren üst düzey becerilerin öğretim programlarına kapsamlı olarak yansıtılmadığını söylemek mümkündür. Bu durum söz konusu becerilerin geniş kapsamda tanımlanması, analiz edilmesi, grafik tasarım disiplini açısından öncelikli yönlerinin belirlenmesi ve bunun öğretim programlarına nasıl yansıtılacağının değerlendirilmesini gerektirmektedir.

21. yüzyıl becerileri kapsamında bilgiye erişim ve değerlendirme, bilgiyi kullanma ve yönetme başlıkları altında incelenmektedir. Bilgiye erişim sürecinde zaman ve kaynakları verimli ve etkili olarak kullanmayı içine almaktadır. Bilgiyi kullanma ve yönetme ise eriştiği bilgiyi amaca uygun bir şekilde doğru ve yaratıcı olarak kullanmak, geniş bilgi akışını yönetmek, bilgiye erişim ile ilgili etik ve yasalar hakkında temel bir anlayışı uygulamak temelinde ele alınmaktadır (Battelle for Kids, 2015). Grafik tasarımında dijital okur-yazarlığın son derece önemli bir beceri olduğu açıktır. Öğrencilerin tasarım sürecinin her aşamasında dijital kaynaklardan bilgiye ulaşma çabası içinde olmaları gerekmektedir. Öğrencilerin dijital okuryazarlık kapsamında amaçlı ve sistemli bir öğretim sürecinin içine dâhil olmaları grafik tasarım sürecinin her aşamasının daha nitelikli bir hale kavuşmasında etkili olacaktır. Grafik tasarım öğretim programlarına öğrenme çıktısı olarak dijital okuryazarlığın eklemesinin yükseköğretimdeki uygulamaların bu açıdan daha sistemli ve standart bir içimde yerine getirilmesinin yolunu açacaktır. Grafik tasarımı alanında incelenen öğrenme çıktılarında bilgi medya teknoloji becerileri içinde yer alan bilgi okuryazarlığı becerisinin edindiği bilgiyi yönetme, bilgiye kolay ulaşma, bilgiyi doğru alanla birleştirebilme ve alanıyla ilgili yenilikleri takip etme becerileri kapsamında ele alındığı görülmektedir.

Grafik tasarımı alanında incelenen öğrenme çıktılarında yaşam ve kariyer becerileri içinde yer alan esneklik ve uyum becerilerine çok az bir oranda yer verildiği görülmektedir. Programlarda ağırlıklı olarak uyum becerilerine yer verildiği görülmektedir. Uyum becerisinin değişen ve gelişen toplumsal dinamiklere uyum sağlama kapsamında ele alındığı görülmektedir. Bir grafik tasarımcıyı çalışma hayatında her açıdan daha güçlü, verimli ve etkili bir hale getirecek olan bu beceri, yükseköğretimde özel olarak üzerinde durulması gereken bir konudur. Bu becerinin öğrencilere kazandırılması için her şeyden önce öğrenme çıktılarında yer bulması öncelikli adım olmalidir.

Grafik tasarımı alanında incelenen öğrenme çıktılarında dijital üretim araçlarını kullanma konusunda yeterlilik kazanılması üzerinde durulduğu görülmektedir. Söz konusu öğrenme çıktıları aynı zamanda grafik tasarımın genişleyen kapsam ve etkinlik alanlarının çerçevesini yeniden çizmektedir. Grafik tasarım veya iletişim tasarımının sürekli bir dönüşüm içerisinde olduğunu ifade eden Heller ve Talarico (2011)'e göre basılı mecradan dijital platformlara geçişle birlikte eğitim uygulama ve süreçlerinin yansıra tasarım alanına özgü faaliyetleri tanımlayan ve kapsamını belirleyen felsefi kavramların da yeniden değerlendirilmesi gerekli hale gelmiştir. Buna göre grafik tasarımı salt sanatsal bir uğraşı olarak görmek artık geçerli bir tanım değildir. Geleneksel anlamda grafik tasarım, tipografik temelli bir uygulama olarak harf ve görüntünün iki boyutlu düzlemde düzenlenmesi yoluyla mesajın iletilmesi olarak tanımlandığında modası geçmiş bir kavram olarak karşımıza çıkar. Zamanla bu alg1 daha da güçlenecektir.

Grafik tasarımın dolayısıyla grafik tasarımcıların etki ve faaliyet alanlarının yeniden tanımlandığı, elektronik ortamlardaki ilerlemelere bağlı olarak kapsamının her geçen gün genişlediği bu dönemde, grafik tasarımı eğitimi veren yükseköğretim kurumlarının da bu dönüşüme ayak uydurması kaçınılmazdır. Grafik tasarımın bir görsel iletişim disiplini olarak kendine özgü temellerinin, görsel gramerinin ve üretim pratiklerinin kuramsal ve uygulamalı olarak öğretimi elbette ki önemini koruyacaktır ve korumalıdır. Fakat iletişim tasarımı alanının gerektirdiği güncel donanım, yetkinlik ve becerilerle desteklenmediği sürece çağın talep ettiği meslek çalışanlarını yetiştirmek imkânsız hale gelecektir. Tasarımcılardan artık grafik dile hâkim olmanın dışında yazılımcı olmaları da beklenmektedir. Elbette ki alanı gereği bir grafik tasarımcıdan -özel ilgi duymuyorsa- bir yazılım mühendisinin işini yapması beklenemez ancak son yıllarda grafik tasarımın yeni uygulama alanlarına doğru genişlediği ve bunda da yeni bilişim teknolojilerinin önemli rol oynadığı bir gerçektir. Artık grafik tasarımcıların dizgi veya görüntü işleme amacıyla kullandıkları masaüstü yazılımlarının alanın gerçek potansiyelini yansıtmakta tek başına sınırlı kaldığı görülmektedir. Bu durum gelecekte, grafik tasarımın geleneksel bir meslek olarak etkinliğini yitirmesine, grafik tasarımcıların ise iş dünyasında kendilerine daha sınırlı sayıda pozisyon bulmalarına yol açacaktır. Davis (2019)'un aktardığına göre, Amerika Birleşik Devletleri Çalışma İstatistikleri Bürosu'nun 2016 yılında yayınladığ 2016-2026 istihdam projeksiyonu raporunda tüm istihdam alanlarındaki toplam büyüme \%7 olarak öngörülürken geleneksel grafik tasarım uygulama alanları için hayal kırıklığı yaratan bir büyüme tahmin edilmektedir. Öte 
yandan, iki yıllık tasarım derecesi gerektiren basılı ve çevrimiçi yayıncılıkta 2.000 istihdam kaybıyla işlerin \%14 oranında azalması beklenmektedir. Dört yıllık bir lisans derecesi gerektiren geleneksel grafik tasarım ve kurumsal kimlik çalışmaları alanında önümüzdeki on yılda mevcut işgücüne yalnızca 11.100 yeni pozisyon eklenerek \%4 ile ABD ortalamasının altında büyüyeceği öngörülmektedir. Söz konusu raporda, önümüzdeki on yılda web tasarımı ve geliştirmenin 24.400 yeni pozisyon ile \%15 büyüyeceği, yazılım endüstrisinin ise 302.500 yeni pozisyon ile \%24 büyüyeceği tahmin edilmektedir. İfade edilen rakamlar ABD için geçerli olan öngörüleri temsil ediyor olsa da önümüzdeki on yılda Türkiye ve birçok ülkede benzer oranları görmek şaşırtıcı olmayacağı düşünülmektedir. Bu nedenle grafik tasarım bölümlerinde okutulan 4 yıllık öğretim programlarının çağın ve alanın güncel gereklilikleri doğrultusunda dönüştürülerek yeniden yapılandırılması son derece zorunludur.

Grafik tasarımı alanı öğretim programlarında incelenen öğrenme çıktılarının 21. yüzyıl becerileri açısından birtakım becerileri içerdiği, birtakım becerileri kapsam açısından tam olarak karşılamadığı, birtakım becerileri ise hiç içermediği görülmüştür. Grafik tasarım öğretim programlarında öğrenme çıktısı olarak kendine yer bulamayan bir becerinin öğretim uygulamalarında da kendine yer bulamayacağı düşünülmektedir. Öğretim uygulamalarında bu becerilere yer veriliyor olsa da bu çalışmaların standart ve sistematik olarak ele alınması, söz konusu becerilerin öğrenme çıktılarına taşınmasını gerektirmektedir. Bu açıdan grafik tasarım alanında 21. yüzyıl becerilerinin öğretim programı öğrenme çıktılarına nasıl entegre edileceği, grafik tasarımı açısından özellikle üzerinde durulması gereken becerilerin neler olduğu, bunların hangi kapsamda programa dahil edileceği üzerinde çalışmalar yürütülmesinin önemli bir gereklilik olduğu söylenebilir. Öğrenme çıktılarına yönelik olarak yürütülecek bu çalışmaların sonucunda program geliştirme çalışmalarının programın diğer boyutlarına da yansıtılması önemlidir. Öğretim programlarında özellikle problem çözme, eleştirel düşünme ve yaratıcılık gibi pek çok temel beceriyi kapsayan becerilerin grafik tasarım öğretimi açısında hangi kapsamda ele alınması gerektiği, alt becerilerinin neler olduğu ve bu becerilerin standart ve sistematik bir yolla öğrencilere kazandırılması için öğrenme çıtısı olarak nasıl ifade edilmesi ya da aşamalandırılması gerektiği konusunda çalışılması gerekmektedir. Gelecek araştırmacıların 21. yüzyıl becerilerini grafik tasarımı temelinde tanımlama, programın ögelerine entegre etme ve gerçekte var olan uygulamaların bu bağlamda incelenmesi konusunda çalışmalar yürütmeleri tavsiye edilir. 


\section{Kaynakça}

Alkış, M. (2020). Üniversite öğrencilerinin 21. yüzyıl becerilerinin bazı değişkenler açısından incelenmesi (Tez No. 643004) [Yüksek Lisans Tezi, Necmettin Erbakan Üniversitesi]. Yüksek Öğretim Kurulu Tez Merkezi.

Anadolu Üniversitesi. (t.y.). Grafik sanatlar bölümü program profili. https://www.anadolu.edu.tr/akademik/ fakulteler/193/grafik-sanatlar-bolumu/program-profili

Anagün, Ş. S., Atalay, N., Kılıç, Z., \& Yaşar, S. (2016). Öğretmen adaylarına yönelik 21. yüzyıl becerileri yeterlilik algıları ölçeğinin geliştirilmesi: Geçerlik ve güvenirlik çalışması. Pamukkale Üniversitesi Eğitim Fakültesi Dergisi, 40(40), 160-175. http://dx.doi.org/10.9779/PUJE768

Ananiadou, K., \& Claro, M. (2009). 21st century skills and competences for new millennium learners in OECD countries. OECD Education Working Papers, 41, 1-33. http://dx.doi.org/10.1787/218525261154

Baril, C. P., Cunningham, B. M., Fordham, D. R., Gardner, R. L., \& Wolcott, S. K. (1998). Critical thinking in the public accounting profession: Aptitudes and attitudes. Journal of Accounting Education, 16(3-4), 381-406. https://www.infona.pl/resource/bwmeta1.element.elsevier-8063de99-a2ec-368f-9579-5e428e2f39bc

Battelle for Kids. (2015). Partnership for 21st century learning: P21 framework definitions. http://www.p21.org/ our-work/p21-framework

Bayrak Özmutlu, E. (2020). The distribution of the mother tongue curricula learning outcomes based on the thinking skills. Çukurova Üniversitesi Eğitim Fakültesi Dergisi, 49(1), 185-224. https://dergipark.org.tr/tr/ download/article-file/1070132

Belet Boyacı, Ş. D., \& Özer, M. G. (2019). Öğrenmenin geleceği: 21. yüzyıl becerileri perspektifiyle Türkçe dersi öğretim programları. Anadolu Üniversitesi Ĕ̈itim Bilimleri Enstitüsü Dergisi, 9(2), 708-738. https://doi.org/ $\underline{10.18039 / a j e s i .578170}$

Cansoy, R. (2018). Uluslararası çerçevelere göre 21. yüzyıl becerileri ve eğitim sisteminde kazandırılması. Insan ve Toplum Bilimleri Araştırmaları Dergisi, 7(4), 3112-3134. https://doi.org/10.15869/itobiad.494286

Cemaloğlu, N., Arslangilay, A. S., Üstündağ, M. T., \& Bilasa, P. (2019). Meslek lisesi öğretmenlerinin 21. yüzyıl becerileri öz yeterlik algıları. Journal of Kirsehir Education Faculty, 20(2), 845-874. https://dergipark.org.tr/ tr/download/article-file/1478660

Colucci, K. (2011). What role will technology play in the future of design education. A. Bennett, \& O. Vulpinari (Eds.), ICOGRADA Design Education Manifesto (s. 62-67) içinde. https://www.icod.org/database/files/ library/IcogradaEducationManifesto_2011.pdf

Creswell, J. W., \& Miller, D. L. (2000). Determining validity in qualitative inquiry. Theory into practice, 39(3), 124-130. https://doi.org/10.1207/s15430421tip3903_2

Davis, M. (2019). Introduction to design futures. Aiga. https://www.aiga.org/aiga-design-futures/introduction-todesign-futures/

Dwyer, C. P., Boswell, A., \& Elliott, M. A. (2015). An evaluation of critical thinking competencies in business settings. Journal of Education for Business, 90(5), 260-269. http://dx.doi.org/10.1080/08832323.2015. $\underline{1038978}$

Ekici, G., Abide, Ö. F., Canbolat, Y., \& Öztürk, A. (2017). 21. yüzyıl becerilerine ait veri kaynaklarının analizi. Ĕ̈itim ve Öğretim Araştırmaları Dergisi, 6(1), 124-134. http://www.jret.org/FileUpload/ks281142/File/12. gulay ekici.pdf

Erten, P. (2020). Öğretmen adaylarının 21. yüzyıl becerileri yeterlilik algıları ve bu becerilerin kazandırılmasına yönelik görüşleri. Milli Ĕgitim Dergisi, 49(227), 33-64. https://dergipark.org.tr/tr/download/article-file /1232057

European Commission. (2016). EU youth report. http://ec.europa.eu/youth/library/reports/youth-report-2015 en. pdf

European Commission. (2019). Horizon 2020: Work programme 2018-2020. https://ec.europa.eu/research/ participants/data/ref/h2020/wp/2018-2020/main/h2020-wp1820-swfs_en.pdf

Göktepe Yıldız, S. (2020). Lise öğrencilerinin 21.yüzyıl becerilerinin bazı demografik değişkenler açısından incelenmesi. Ulakbilge, 51(2020 Ağustos), 884-897. https://doi.org/10.7816/ulakbilge-08-51-02

Güler, A., Halıcıoğlu, M. B., \& Taşğın, S. (2013). Sosyal bilimlerde nitel araştırma yöntemleri. Seçkin Yayıncılık. 
Günüç, S., Odabaşı, H., \& Kuzu, A. (2013). 21. yüzyıl öğrenci özelliklerinin öğretmen adayları tarafından tanımlanması: Bir twitter uygulamas1. Eğitimde Kuram ve Uygulama, 9(4), 436-455. https://dergipark.org.tr/tr/ download/article-file/63366

Gürültü, E., Aslan, M., \& Alıc1, B. (2019). Ortaöğretim öğretmenlerinin 21. yüzyıl becerileri kullanım yeterlikleri. Hacettepe Üniversitesi Eğitim Fakültesi Dergisi, 35(4), 780-798. https://doi.org/10.16986/HUJE. 2019051590

Heller, S., \& Talarico, L. (2011). An education manifesto for Icograda. A. Bennett, \& O. Vulpinari (Eds.), ICOGRADA Design Education Manifesto (s. 82-85) içinde. https:/www.ico-d.org/database/files/library/ IcogradaEducationManifesto_2011.pdf

Huang, N. T., Chang, Y. S., \& Chou, C. H. (2020). Effects of creative thinking, psychomotor skills, and creative self-efficacy on engineering design creativity. Thinking Skills and Creativity, 37, 1-10. https://doi.org/10.1016/ j.tsc. 2020.100695

Kassim, H., Nicholas, H., \& Ng, W. (2014). Using a multimedia learning tool to improve creative performance. Thinking Skills and Creativity, 13, 9-19. https://doi.org/10.1016/j.tsc.2014.02.004

Kayhan, E., Altun, S., \& Gürol, M. (2019). Sekizinci sınıf Türkçe öğretim programı (2018)’nın 21. yüzyıl becerileri açısından değerlendirilmesi. Adnan Menderes Üniversitesi Eğitim Fakültesi Eğitim Bilimleri Dergisi, 10(2), 20-35. https://dergipark.org.tr/tr/download/article-file/904668

Koçak, Ö., \& Göksu, İ. (2020). Öğrencilerin 21. yüzyıl beceri düzeyleri ve beceriler arasındaki ilişkinin incelenmesi. Inönü Üniversitesi Eğitim Fakültesi Dergisi, 21(2), 772-784. https://doi.org/10.17679/inuefd. $\underline{656784}$

Kozikoğlu, İ., \& Özcanlı, N. (2020). Öğretmenlerin 21. yüzyıl öğreten becerileri ile mesleğe adanmışlıkları arasındaki ilişki. Cumhuriyet International Journal of Education, 9(1), 270-290. https://dergipark.org.tr/tr/ download/article-file/1012726

Kurudayığlu, M., \& Soysal, T. (2018). 2018 Türkçe dersi öğretim programı kazanımlarının 21. yüzyıl becerileri açısından incelenmesi. Ahi Evran Üniversitesi Sosyal Bilimler Enstitüsü Dergisi, 5(2), 483-496. https://doi. org/10.31592/aeusbed.621132

Millı̂ Eğitim Bakanlığı. (2005). İlköğretim Türkçe dersi öğretim programı ve kılavuzu (1-5. Sınıflar). Millî Eğitim Bakanlığı Yayınları.

Montag Smit, T., \& Maertz Jr, C. P. (2017). Searching outside the box in creative problem solving: The role of creative thinking skills and domain knowledge. Journal of Business Research, 81, 1-10. https://doi.org/10. 1016/j.jbusres.2017.07.021

Nacaroğlu, O. (2020). Özel yetenekli ve normal gelişim gösteren öğrencilerin 21. yüzyıl becerilerinin incelenmesi. Ankara Üniversitesi Eğitim Bilimleri Fakültesi Dergisi, 53(2), 693-722. https://doi.org/10. 30964/auebfd.615067

O’Donnell, A., \& Hmelo Silver, C. E. (2013). What is collaborative learning? An overview. In C. E. Hmelo Silver, C. A. Chinn, C. K. K. Chan \& A. O’Donnell (Eds.), The International Handbook of Collaborative Learning. Routledge.

Organization for Economic Cooperation and Development (OECD). (2013). Ready to learn: Students' engagement, drive and self beliefs Volume III. OECD Publishing. http://www.oecd.org/pisa/keyfindings/ PISA2012-Vol3-Chap3.pdf

Öztermiyeci, E. (2019). Türkiye'de ulusal program ve uluslararası Bakalorya programı ögrencilerinin 21. yüzyıl becerilerine ilişkin algıları (Tez No. 596332) [Yüksek Lisans Tezi, Maltepe Üniversitesi]. Yüksek Öğretim Kurulu Tez Merkezi.

Park, J. A., \& Kim, B. J. (2009). Critical thinking disposition and clinical competence in general hospital nurses. Journal of Korean Academy of Nursing, 39(6), 840-850. https://doi.org/10.4040/jkan.2009.39.6.840

Scott, J. \& Marshall, G. (2015). A dictionary of sociology (3 rev. ed.). Oxford University Press.

Sears, D. A., \& Reagin, J. M. (2013). Individual versus collaborative problem solving: Divergent outcomes depending on task complexity. Instructional science, 41(6), 1153-1172. https://doi.org/10.1007/s11251$\underline{0139271-8}$

Trilling, B., \& Fadel, C. (2009). 21st century skills: Learning for life in our times. Jossey-Bass/Wiley. 
Tuğluk, M. N., \& Özkan, B. (2019). MEB 2013 okul öncesi eğitim programının 21. yüzyıl becerileri açısından analizi. Temel Eğitim Dergisi, 1(4), 29-38. https://dergipark.org.tr/tr/download/article-file/875766

Uluyol, Ç., \& Eryılmaz, S. (2015). 21. yüzyıl becerileri ışığında fatih projesi değerlendirmesi. Gazi Üniversitesi Gazi Eğitim Fakültesi Dergisi, 35(2), 209-229. http://www.gefad.gazi.edu.tr/tr/download/article-file/77533

Voogt, J., \& Roblin, N. P. (2012). A comparative analysis of international frameworks for 21st century competences: Implications for national curriculum policies. Journal of Curriculum Studies, 44(3), 299-321. https://doi.org/10.1080/00220272.2012.668938

Yalçın, S. (2018). 21. yüzyıl becerileri ve bu becerilerin ölçülmesinde kullanılan araçlar ve yaklaşımlar. Ankara Üniversitesi Ĕ̈itim Bilimleri Fakültesi Dergisi, 51(1), 183-201. https://doi.org/10.30964/auebfd.405860

Zeybek, G. (2015). Lise öğrencilerinin 21. Yüzyıl öğrenme becerileri kullanım düzeylerinin belirlenmesi. International Journal of Social Sciences and Education Research, 5(2), 142-156. https://doi.org/ $\underline{10.24289 / \mathrm{ijsser} .505263}$ 